On the Economics of the Exodus: An Institutional Economic Reconstruction of Biblical Cooperation Failures

Sigmund Wagner-Tsukamoto 


\title{
On the Economics of the Exodus: An Institutional Economic Reconstruction of Biblical Cooperation Failures
}

\section{KEYWORDS}

Interest conflicts; institutional economic theory; cooperation dilemmas; prisoners' dilemma; economic man.

\begin{abstract}
In difference to Genesis, the Exodus interactions between Egypt and Israel broke down. The paper argues that Moses and the pharaoh acted like 'rational fools' when they escalated problems regarding industrial relations and common pool resources. Pluralism was not mastered as an interaction condition in international relations. The paper explores these issues through the prisoner's dilemma, in which mutual loss is the outcome. The unsuccessful ordering of economic institutions (governance, property rights, reward systems) is suggested as the key source of conflict. In this way, the paper specifies the thesis that the Bible instructs the organisation of human interactions in rational, economic terms. The exodus is not analysed and praised, as conventionally done by theology and religious economics, as the resolution of conflict over religious values and the escape of Israel from a claimed system of slavery
\end{abstract}




\section{On the Economics of the Exodus: An Institutional}

\section{Economic Reconstruction of Biblical Cooperation Failures}

“Then a new king, who did not know about Joseph, came to power in Egypt." (Exod. 1.8)

\section{Introduction}

Conflict among the nations of the Near East and Middle East has a long history and violent tradition. The book of Exodus discusses such conflict. It tells the story of Egypt and Israel failing to maintain cooperation as it had developed in Genesis. The paper reconstructs this cooperation failure in institutional economic terms, specifically in relation to the way economic institutions are set up. Economic institutions are interpreted, broadly speaking, as incentive structures. This reconstruction implies a secular, rational function of Bible stories for organising human interactions, as proposed by Wagner-Tsukamoto (2001) for Genesis. ${ }^{1}$

There have been few attempts to analyse the Old Testament in non-metaphysical, economic terms, despite a considerable body of theologically oriented, economic research on the Old Testament, e.g. on interest paid for loans or the true value of goods. The economic analysis of the exodus has been generally neglected. The present paper closes such gaps. It differs in methodological, theoretical and practical-normative terms from the few existing, religious economic analyses of the exodus. First, the paper reconstructs decision-making of Moses and the pharaoh as 'economic man-behaviour' in a prisoner's dilemma. Game theoretical concepts and rational choice theory are applied in methodical perspective only but

\footnotetext{
${ }^{1}$ Miller (1994: 760-1) hinted at such a function for Genesis regarding contracting.
} 
not in theoretical perspective. This contrasts with Brams (1980), who reconstructed decisionmaking of Moses, the pharaoh and God in micro-economic terms, advancing the thesis that they were rational, economic game players (Brams 1980: 79-94, 166-8). The paper questions whether Moses was a heroic game player (Brams 1980: 174; similarly Gordon 1989: 8-9), that the exodus reflected a religious power and obedience game that was played by God to raise his image and reveal his omnipotence (Brams 1980: 81-89, 175) and that the exodus was primarily caused by rebellion against an inhumane system of slavery (Brams 1980: 81). Second, in theoretical perspective, the paper attributes the breakdown of cooperation to intervention failures with economic institutions. It suggests that the pharaoh and Moses played out contribution-distribution conflicts in the face of 'defective', incentiveincompatible institutional structures. Consequently, the paper strictly develops practicalnormative implications regarding the (re)design of incentive structures. Cooperation problems are not examined as the human condition, as done by religious economics and theology (e.g. Noth 1966; Brams 1980; Westermann 1987; Gordon 1989; Wildavsky 1994; Paris 1998).

Third, the paper theorizes more parsimoniously than religious economics and theology. The Bible is approached as 'text', independent of questions of divine or human authorship (in detail Wagner-Tsukamoto 2001; see also Miller 1994: 756). The exodus and especially the idea of God are reconstructed in rational, scientific terms. God is interpreted as an agent who behaviourally intervened in interactions between the pharaoh and Moses. His role is compared to the one of the prosecutor in the prisoner's dilemma. In more abstract terms, the idea of God is transcended for economic and non-economic cooperation principles. The paper here departs from the religious economics of Brams (1980), Gordon $(1989,1994)$ or Paris (1998) and the more so from theology (e.g. Noth 1966; Wildavsky 1994; also Westermann 
1987), which subscribe to a metaphysical concept of a personal, omnipotent God and noneconomic cooperation principles.

Fourth, the paper succeeds to explain the exodus more conclusively and more comprehensively than religious economics and theology. For example, Brams (1980) overlooked the pharaoh's performance quota increase and explicit, conceptual junctims between Exodus and Genesis. The present paper proposes an institutional economic rationale for junctims between Exodus and Genesis.

In the following, section 2 outlines the nature and purpose of dilemma analysis in institutional economics. Section 3 reconstructs the exodus in institutional economic terms. It argues that Moses and the pharaoh were caught up in an economic dilemma structure, that they failed to intervene with incentive structures to resolve conflict and that their 'economic man-behaviour' yielded mutual loss. Section 4 examines the counter-story to the exodus, namely how in Genesis cooperation developed between Egypt and Israel by means of economic intervention. Section 5 concludes the paper.

\section{Analytical Framework: Institutional Economics and Dilemma Analysis}

Institutional economics analyses incentive structures, e.g. governance structures, property rights arrangements or pay systems, in order to examine cooperative or non-cooperative outcomes of social interactions. Incentive structures set out decision-making rights of agents and specify contribution arrangements and distribution arrangements. Agents are expected to contribute capital in one form or another to an interaction and they expect to receive capital 
distributions in return. Cooperation is diagnosed if interactions yield mutual gains (see elements three, four and five of Figure 1). This framework projects theoretical analysis in practical-normative perspective by advising on the (re)design of incentive structures. Incentive structures are to be designed in a way so that cooperation results (if cooperation is the desired interaction outcome): “[T]he rules of certain social 'games' must be changed whenever it is inherent in the game situation that the players, in pursuing their own ends, will be forced into a socially undesirable position.” (Luce and Raiffa 1957: 97) Successful (failing) cooperation is strictly treated as a problem of incentive-compatible (incentiveincompatible) institutional structures (Williamson 1985; 1998; Buchanan 1987a; 1987b; 1995; Homann 1990; 1994; 1997; Vanberg 1994; Wagner-Tsukamoto 2003; similarly von Neumann and Morgenstern 1947: 44, 49; Stigler and Becker 1977; 76).

Insert about here: Figure 1

Institutional economic theory and practical intervention is methodically instructed, like any scientific research program, by heuristic concepts. They map out an 'axiomatic' sub-theoretical, pre-empirical, quasi-tautological - problem formulation and problem-solving apparatus (Wagner-Tsukamoto 2003; see also Lakatos 1970: 132-7; 1978, 4, 47-52, 148; Popper 1978: 67; Hofstadter 1979: 17-20, 183; Penrose 1989: 135-7, 538, 558). Two key heuristics of institutional economics are the ideas 'dilemma structure' and 'homo economicus' (see elements one and two of Figure 1). Simply expressed, the homo economicus is a situatively geared calculus of self-interested choice. The idea of the dilemma 
structure suggests that interacting agents simultaneously encounter common interests - to cooperate in order to reap socially desirable outcomes such as mutual gains - and conflicting interests - to organise contributions to and distributions from the interaction to one's own advantage and to the disadvantage of other agents (in detail, Homann 1994; 1999).

Institutional economics here models cooperation dilemmas as a nonzero-sum game, that means it models a scenario in which all agents lose because of self-interested choice, despite the possibility that all could gain if only cooperation succeeded. In a dilemma structure, selfinterested, rational choice of the individual seems to maximize own gains but actually results, because of the rational choice reaction of others, in mutual loss. The prisoner's dilemma and the commons dilemma are classic illustrations (Luce and Raiffa 1957: 94-7; Hardin 1968: 1244-6; see also Libecap 1989; Maskin 1994; Hardin 1996; Wagner-Tsukamoto 2003). Williamson (1985: 32-4, 42; 1975: 135-6) speaks of the "contracting dilemma", Buchanan (1975: 130-46) of the "punishment dilemma" or behavioural economics of "rational foolishness" (Sen 1990; 43). In general, dilemma analysis has a long history in philosophy and in the social sciences. Unless the resolution of social conflict is taken for granted, social research needs to (heuristically) invoke a dilemma model. Nussbaum (1986) hinted at this for the modelling of tragic conflict in Greek philosophy; the Bible's concept of the original sin can be similarly interpreted (Wagner-Tsukamoto 2001); or the model of the 'war of all' predominantly served Hobbes as a tool to discuss the prevention of war (Mintz 1962; Homann and Suchanek 1989).

With the concepts 'dilemma structure' and 'economic man' institutional economics analyses cooperation problems as a situational condition of 'defective' incentive structures. They instruct theoretical analysis and practical intervention, which enables 'even' merely self- 
interested agents to escape from dilemmatic conflict and reap socially beneficial outcomes. Only for heuristic, instrumental purposes, agents are modelled as economic men and social interactions as dilemma structure (in detail Wagner-Tsukamoto 2003: 33-43; see also Machlup 1967: 7, 11; 1978: 292-9; Becker 1976: 5, 13-14; 1993: 402; Buchanan 1987b: 5163; Suchanek 1993; 1994; Homann 1994; 1999; Persky 1995: 223-4, 230; Brennan 1996: 256-7; Homann and Suchanek 2000: 32-40). The functional nature of 'dilemma structure' and 'homo economicus' can be illustrated through the analogy of the car crash test (See Wagner-Tsukamoto 2001: 2003).

Hence, (institutional) economics attributes "rational foolishness" not to the human condition, such as deficits in rationality or compassion and it does not favour pedagogic intervention, as behavioural economics does (e.g. Simon 1976; 1993; 1997; Margolis 1982; Etzioni 1988; Sen 1990; Hollis 1994; in small degrees even Williamson 1998: 2, 10; 1985 : 391). For reasons of problem dependence, economics abstracts from the human condition, which is "non est disputandum" (Stigler and Becker 1977: 76). Only for behavioural research, the concept of an economic dilemma structure and of the homo economicus can be rejectedon grounds of problem dependence but not on grounds of being unrealistic or immoral (in an empirical-behavioural or normative-behavioural sense).

Especially under interaction conditions of pluralism and cultural diversity, institutional economics, heuristically grounded in the ideas 'dilemma structure' and 'economic man', is likely to be more effective, more efficient and more moral than behavioural approaches (Wagner-Tsukamoto 2003: Chapter 8). The paper spells out this thesis with regard to the story of the exodus. 


\section{Dilemmatic Conflicts and the Breakdown of Cooperation in Exodus}

The book of Exodus tells of problems regarding population management and industrial relations. It describes how Egypt and Israel escalated such problems and ultimately got involved in a futile dilemma game, with mutual loss the outcome. The following reconstructs these events in institutional economic terms. The reconstruction suggests that Moses and the pharaoh failed to intervene with incentive structures to resolve conflict.

\subsection{Unsuccessful Conflict Resolution Between Egypt and Israel: Appeal, Confiscatory Rule Change and Tit-for-tat Retaliation}

At the outset of the book of Exodus, uncontrolled population growth threatened to exhaust Egypt's resources in water, livestock and fertile land: "The Israelites were fruitful and multiplied greatly and became exceedingly numerous." (Exod. 1.6; also Gen. 47.27; see also Gordon 1989: 16; Paris 1998: 54-5). Egypt and Israel encountered a common pool problem with the "commons dilemma" looming (Hardin 1968; also Libecap 1989). As one society, Egypt and Israel had a common interest to cooperate, to restrain population growth and maintain mutually beneficial industrial relations. But individual Israelites (and Egyptians) had an interest to exercise reproduction rights as had Israel and Egypt as sub-groups an interest in shifting population balances in their favour. In this respect, conflicting interests existed. Related to increasing population imbalances between Egypt and Israel, the pharaoh also feared of being attacked by Israelites or the Israelites siding with a foreign attacker (Exod. 
Although Exodus is implicit on this, the pharaoh may have considered appeal to resolve the population problem, hoping that Israelites voluntarily constrained reproduction rates once asked to do so (Exod. 1.8-14). Appeal, however, does not resolve interest conflicts. It leaves the incentive logic for reproduction decisions unchanged. It could not make Israelites formulate and implement a constraint on population growth on grounds of self-interested, rational choice. Indeed, appeal is likely to aggravate existing interest conflicts. It raises awareness of a looming, unresolved conflict and signals forthcoming rule change. Because of appeal, Israelites and Israel as group could be expected to make extended, immediate efforts to reproduce. Hardin (1968: 1246) discussed this as self-elimination tendencies of non-economic strategies for resolving common pool problems.

After the failure of appeals, the pharaoh resorted to coercion and confiscation: $\mathrm{He}$ ordered the killing of Israelite baby boys (Exod. 1.15). Confiscation is likely to be as ineffective as appeal but more so than appeal has confiscation a high potential to escalate interest conflicts. North's (1993) ruler-constituent analogy, in which a ruler confiscates property of constituents by reneging promises on wealth distribution, is illustrative. In the specific scenario depicted in Exodus, the confiscation order of the pharaoh should instigate rational Israelites to make extended efforts to reproduce. First, the survival chance of an Israelite baby boy had not decreased to zero since institutional arrangements of Egyptian society saw Israelite maids in charge of baby nursing (Exod. 1.15-16; also Exod. 2.5-7). Ineffectiveness could be expected, at least to a degree. Moses is an example and Exodus (1.12) confirms that the pharaoh's killing order failed to constrain population growth. Second, as far as the pharaoh actually succeeded to kill Israelite baby boys, rational Israelites could be 
expected to engage in tit-for-tat counter-confiscation. Escalating interaction dynamics of the commons dilemma or prisoner's dilemma illuminate this (Hardin 1968; see also Axelrod 1986). Since child nursing was in the hands of Israelite maids, the opportunity for retaliation existed 'already' within the 'moves of the game'. The plague of the death of Egyptian infants (Exod. 11.4-7; also Numbers 33.3-4) can be interpreted as such retaliatory counterconfiscation. It appears that even outright slaves can, in degrees, counter-defect within the 'moves of the game' (and the more so if they succeed to manipulate the rules of the game). Knight (1948: li) and Buchanan (1995) indicated this, Knight with specific reference to a pharaoh's behaviour as a ruler. Also, as far as the pharaoh's killing order succeeded, a scarcity in males should make rational Israelites change their reproduction behaviour, switching from monogamy to polygamy. Genesis hinted at this (Gen. 16.15; 19.31-8; 21.1-2; 25.1-2, 6; 29.1630). This, again, leaves population problems unresolved.

Related to the escalating population problems, Egypt and Israel got involved in conflict regarding industrial relations, namely the slavery-like treatment of Israelites by the pharaoh and pay-performance disputes (Exod. 1.11-14; 6.9). In particular, the pharaoh raised contribution standards while keeping wage distributions constant. He ordered Israelites to provide on own account input - straw - to brick production: "You are no longer to supply the [Israelite] people with straw for making bricks; let them go and gather their own straw. But require them to make the same number of bricks as before; don't reduce the quota." (Exod. 5.6-8; also Exod. 5.11, 13-14, 18-19) This rule change implied longer working hours and, if straw had to be paid for, monetary costs. The pharaoh here broke a previous settlement over wage and performance levels, in effect confiscating wealth promised to his workforce. As a result, contribution-distribution arrangements ('the payoff matrix'), which already had been 
distorted by the pharaoh's population policy, were made further "incentive-incompatible", to use Williamson's (1985: 27-30, 76) terminology.

The ten plagues can be read as Israel's retaliatory response to the pharaoh's confiscation policies regarding industrial relations and common pool resources. Each of the plagues, not dissimilar to the effects of a 'strike', destroyed some of Egypt's wealth. Besides having a retaliation motive, the Israelites could, while being in search for straw throughout Egypt, sabotage resources and farming projects. It is difficult to imagine that the highly industrialized Egypt described in Genesis and Exodus did not have some biological or other defences in place against naturally occurring plagues like frogs, flies or gnats (Exod.:

Chapters 7-10). But it was probably quite helpless regarding planned, man-made disasters. ${ }^{2}$ This contrasts with an interpretation of the plagues as godly miracles or natural events (e.g. Tullock 1981: 70-1).

\subsection{Mutual Loss as Interaction Outcome}

Exodus reports stories of murder and destruction as outcomes of unresolved conflict over population management and industrial relations. Mutual loss resulted with the 'war of all' breaking out, as Hobbes may put it. This war was not so much a religious crusade but a war about goods and capital gains, relating to reproduction rights, fertile land, food, water and industrial relations.

As a result of the exodus, Egypt lost a considerable amount of human capital and

\footnotetext{
2 If the system of a barter tax on crop (Gen. 41.33-7) had been scrapped by the pharaoh of Exodus, Egypt would have been ill-prepared to survive such disasters.
} 
economic benefits from cooperating with the Israelites (Exod. 14.5); it suffered the costs incurred by the ten plagues (Exod.: Chapter 6-11); it was plundered in the course of the exodus (Exod. 3.22; 12.36-7); and its army was destroyed when chasing the Israelites into the desert (Exod. 14.27-8). But not only Egypt lost. Israel was 'liberated' from an affluent society, in a sense from paradise. It lost economic privileges that had come with the emigration to Egypt, such as sharing into wealth creation; being buffered against economic and natural disasters; and being protected by Egypt's legal, judicial and military apparatus against internal, civil unrest and against attacks by other nations.

After the exodus from Egypt, Israel had to go through a costly resettlement process. Exodus (16.35) and Numbers (33.38) speak of a first part of the exodus journey lasting 40 years. During this journey, the Israelites were plagued by thirst, famine, disease and the natural conditions of the desert (Exod. 14.3, 20;15.22-6; 16.3, 10;17.2-3; 19.9, 16; Num. 33.14). They were exposed to the attack of foreign armies (Exod. 13.18; 17.8; 23.27-30) and they had to recoup their homeland which, during their emigration to Egypt, had been lost to other nations (Num. 33.40, 51-5; Deut. 7.1-6). Israel also had to bear the costs of setting up judicial and legal institutions for maintaining social order (Exod.: Chapters 20-31). In the initial stages of the exodus, it was torn apart by civil unrest and an anti-pluralistic war for a value consensus, which led to mass executions within the Israelites own ranks (Exod. 14.11$12 ; 16.1-2,8 ; 17.4 ; 32.27-9) .^{3}$

Regarding these outcomes of the exodus, theology and religious economics probably take a too optimistic view. For example, religious economics interprets the exodus and

${ }^{3}$ This can be interpreted as a first attempt of the liberated Israel to come to terms with the institutional problem (Exod. 14.11-12; 16.1-2, 8; 17.4; 32.27-9). Future research can examine how this behavioural approach was partly backed up, partly replaced by economic policies on constitutional law-making. The Ten Commandments and their regulatory derivatives here 
Moses' behaviour as "heroic” (Brams 1980: 174) and as "solution by faith" (Gordon 1989: 910, similarly Noth 1966: 68; Paris 1998: 55). Since both nations were made worse off, the present paper is more critical. It interprets the exodus as a nonzero-sum game that went badly wrong. Gordon (1989: 10) seemingly noted this when commenting that there was "no soil" and "no city" in the desert. As in the prisoner's dilemma and the commons dilemma, no winwin solutions were generated. In a sense, both Egypt and Israel self-evicted from 'paradise'. A common interest in cooperation and mutual gains was violated. Both parties lost because of self-interested choice, despite the possibility that both could have won if only cooperation had succeeded. From an economic point of view, true heroes, who solved problems to the mutual advantage of Egypt and Israel, are probably better reflected by Joseph and the pharaoh of Genesis (see section 4).

\subsection{The Failure to Intervene with Economic Institutions}

The lacking success of appeal, confiscation and counter-confiscation can be related to the failure of these policies to intervene with incentive structures. In particular, they failed to equilibrate conflicting interests of Egypt and Israel.

The population problems and industrial relations problems raised in Exodus reflect classic contribution-distribution conflicts. They have been well researched in the institutional economic literature on common pool problems and industrial relations (e.g. Hardin 1968; Buchanan 1975; Williamson 1975; 1985; Libecap 1989). Especially wage and workload disputes have a long history in industrial relations. Already the studies of Taylor $(1903 ; 1911$, 
1912) hinted that economic rule change is required to prevent confiscatory behaviour of managers and union bosses (Wagner-Tsukamoto 2003). Incentive structures need to be intervened with in order to prevent the escalation of conflict. The works of Hayek, Buchanan, North, Williamson or Vanberg are instructive as is Nyland's $(1998 ; 1996)$ discussion of the mutual gains strategy for resolving conflict in industrial relations (See also Wagner 2000). ${ }^{4}$ It is important to note that not only the pharaoh could intervene with incentive rules but also Moses. Besides each side playing the game (making choices within set rules), both had, albeit in different ways and degrees, competency rights over the rules of the game, especially regarding ad-hoc confiscations. Moses held competency rights similar to the ones of a 'union boss' in collective bargaining processes. He commanded the Israelites and could confiscate through 'wild strikes', sabotage and other defections. He could also use confiscation possibilities as a bargaining chip in negotiations over rule change.

The crucial issue for solving in economic terms industrial conflict and population problems is to install structures, which equilibrated conflicting interests. In Exodus, population problems could have been resolved in this way through taxing families with many children higher than those with few; through setting out property rights to reproduction, possibly even in inter-generational perspective (see Wagner-Tsukamoto 2001); through introducing a state-run pension scheme or a state-run nursing system for the elderly; etc. Such measures would have changed incentives for individual reproduction behaviour. Hardin (1968) argued for this early on. Such economic proposals have little in common with theological population management that relies on faith and godly wisdom, as it is also advocated by religious economics (e.g. Gordon 1989; Paris 1998; also Brams 1980).

\footnotetext{
${ }^{4}$ Such normative implications regarding the redesign of incentive structures are missing from evolutionary economics, which expects cooperation to emerge through the moves of the game
} 
Similarly, industrial relations problems could have been approached in economic terms, for example, through installing collective bargaining arrangements. Meta-structures would have been needed, too, which organised and safeguarded collective bargaining from outside the pharaoh's and Moses' sphere of rights to rule change. North (1993: 14) implied in this connection that a ruler has to effectively self-bind himself not to retreat from promises made to constituents regarding contributions and distributions. As discussed, both the pharaoh and Moses did not master this challenge. They failed to design economic structures and meta-structures which would have resolved interest conflict.

\section{4. 'Economic-man' Behaviour in a Dilemma Structure}

Exodus explicitly reconnected to the snake metaphor when it reports that the pharaoh and Moses were "throwing snakes" at each other (Exod. 7.8-13, also Exod. 4.3-4, 17). The snake metaphor is one of the Bible's references to a calculus of self-interest ('the homo economicus'). It was first invoked when Adam and Eve were seduced in paradise (Gen. 3.13; see Wagner-Tsukamoto 2001). In Exodus, the throwing of snakes can be read as a reference to confiscatory 'economic man behaviour' in conflict over population management and industrial relations.

Not dissimilar to interactions in the paradise scenario in Genesis, the pharaoh and Moses failed to see that in a situation of incentive-incompatible institutional structures selfinterested, 'confiscatory' choice undermined cooperation. Since their 'economic-man behaviour' yielded mutual loss, one might be tempted to criticize the pharaoh and Moses as

(e.g Axelrod 1986). The exodus story here provides a warning to evolutionary economics. 
'rational fools', condemn the model of economic man and possibly economics in general. Behavioural economics argues this way (e.g. Sen 1990). However, such critique overlooks that (institutional) economics only heuristically 'throws snakes'. The very purpose of applying the model of economic man, as of the idea of the dilemma structure, is to prevent rational foolishness. Institutional economics specifies the purpose of 'throwing snakes' in relation to the design of institutional structures which equilibrate interests and create mutual gains. Exodus hinted at this when it stated that the "throwing of snakes" was not a "vice" in itself but could “... perform miraculous signs” (Exod. 4.17).

Moses and the pharaoh, however, did not know about such an instrumental, methodical 'playing' of the model of economic man. They seemingly lacked institutional economic wisdom in this respect - and for this they can be criticized. At the very outset of the book of Exodus, this problem was hinted at when Exodus (1.8) stated that the pharaoh did "not know about Joseph", who, like no other biblical figure, stood for economic conflict resolution (see section 4). Early on, Exodus (2.16-17) similarly indicated that Moses 'knew little about Joseph', when it illustrated his non-economic, violent handling of conflict over water usage (see also Exod. 2.11-12). This was underlined by the warning of Jacob (Israel) not to bestow leadership functions on members of the house of Levi, to which Moses belonged: "Let me not enter their council, let me not join their assembly ... Cursed be their anger, so fierce, and their fury, so cruel!" (Gen. 49.5-7) References to "councils" and "assemblies" are especially worthwhile noting. They can be interpreted as references to governance structures, such as collective bargaining and co-determination schemes. As discussed, in order to analyse economic conflict resolution through such structures, the model of economic man and the idea of the dilemma structure are needed as a design tools. 


\subsection{Prisoners and Prosecutor: the Role of God and Value Fundamentalism}

The question has to be raised why Moses and the pharaoh failed to develop 'economic wisdom' regarding institutional governance. In particular, why did they fail to see that their 'economic man-behaviour' was rationally foolish and would over time lead to mutual loss? In terms of the prisoner's dilemma analogy, it is important to inquire by whom and how a prisoner's dilemma was installed for Moses and the pharaoh. It appears that divine intervention played a significant role.

In difference to Genesis, in Exodus God did not show Egypt and Israel economic options for rule-making and choice behaviour which could have prevented mutual suffering. Figuratively expressed, it was God who did not let Moses and the pharaoh 'know about Joseph' (see section 4). God's role in this respect can be compared to the one of the prosecutor in the prisoner's dilemma. In the prisoner's dilemma it is the prosecutor who makes rational economic agents behave as 'rational fools', by separating the prisoners into different rooms and preventing them to consult each other over choice options. In Exodus, God acted as a comparable catalyst and source of conflict. He prevented, by means of psychological, 'value fundamentalist' intervention, Moses and the pharaoh from economically wise intervention. God made Moses and the pharaoh retaliate and not get involved in negotiations over social problems and governance structures (Exod. 7.3-4, 13, $22 ; 8.15,19,32 ; 9.7,12,34-5 ; 10.1-2,20,27 ; 11.9-10)$. Thus, God at least contributed to 'rationally foolish' outcomes. Anti-pluralistic implications emerge regarding God's role in the 
exodus. This interpretation is compatible with Brams' (1980: 86-93) suggestion that divine intervention in Exodus reflected a personal power revelation game of God, with the pharaoh and Moses being “puppets” of God.

As for the prosecutor in the prisoner's dilemma, the idea of God in Exodus needs to be transcended for cooperative and non-cooperative interaction principles. In this connection, Brams (1980: 88) evaluated a claimed power revelation game of God favourably since it seemingly "liberated" Israel. The present paper is here more critical regarding the idea of liberation. 'Liberation' did not solve cooperation problems: the exodus occurred and mutual suffering resulted. For assessing the role of God in Exodus and hereof-derived cooperation principles a crucial question is why did God not prevent mutual suffering and use his omnipotence constructively as the God of Genesis had done? Also, why was 'economic trauma' necessary at all? And why did God only after the plagues psychologically intervene and make the Egyptians favourably disposed towards cooperation with Israel (Exod. 12.36)? Could God not have psychologically intervened from the outset and made the pharaoh and Moses cooperate? Brams in this respect proposed that the economic damage caused by the ten plagues was more revealing regarding God's power than psychological trauma. But it can be questioned why economic trauma should be more revealing than psychological trauma. Also, Brams seemed to overlook that not only Egypt but also Israel was economically traumatized because of the exodus. Such issues of economic trauma are well illuminated by the prisoner's dilemma game and related economic interaction principles which advise on the resolution of the dilemma.

Also, the exodus implied that interactions moved out of contexts that were defined by pluralism as interaction condition. Miller (1994: 755, 759; 1993: 477; also Gordon 1989: 10) 
hinted at this for Genesis when relating the breakdown of contracting to a return to "iron age". But then Gordon's analysis of Moses' behaviour as "heroic" and the exodus as "solution by faith" (Gordon 1989: 7-9; also Noth 1966: 68; Wildavsky 1994: 38, 48; Paris 1998: 41 -2) seems to endorse such a return to a pre-modern age. The idea of conflict resolution by faith leaves conflict handling outside the realm of human wisdom. Theology and religious economics here proceed on metaphysical grounds. This approach is difficult to reconcile with philosophical and scientific research in the tradition of the Enlightenment. The latter reconstructs metaphysical concepts in non-metaphysical terms. Godly intervention is reconstructed as an economic disequilibration process of interests that was driven by value fundamentalism. In this respect, the story of the exodus seemingly outlines principles how not to proceed when socially beneficial governance is desired in pluralistic contexts.

\section{Genesis versus Exodus: Mutual Gains as Interaction Outcome}

The exodus is preceded by successful cooperation between Egypt and Israel in Genesis. Since there are explicit references to a conceptual junctim between Genesis and Exodus (Gen. 40.23; Exod. 1.8), a reconstruction of the exodus is incomplete without a review of succeeding cooperation between Egypt and Israel. ${ }^{5}$

Because of shortages in farming skills, industrial skills, administrative skills and managerial skills, the Egypt of Genesis had welcomed immigration (Gen. 37.28, 36; 39.4-6, $22-3 ; 40.2 ; 41.2-7,15,40-7 ; 45.5,10-11,18 ; 46.3-5 ; 47.6,22-3)$. And affluence

\footnotetext{
${ }^{5}$ Future research in this respect can spell out a "centre-thesis" for the Old Testament that differs from the ones of theology (e.g. Revetlow 1985: 128).
} 
differentials between Egypt and Israel provided Israelites with incentives to emigrate (Gen. 41.27, 30, 54, 57; 45.6; also Gen. 12.10; 37.25, 43.11-12). Then, the relationship between Egypt and Israel did not resemble the one of a slave master and slaves. For example, Israelites enjoyed freedom of movement within and outside Egypt (Gen. 12.10; 41.43; 42.1-2; 43.1-2; 47.27; 50.7-11; also Exod. 2.15; 5.6-8).

The archetypical case of the Israelite 'non-slave' was Joseph. He was sold to Egypt by his brothers (Gen. 37. 27-28, 36) but, once in Egypt, ascended to the top of its industrial hierarchy (Gen. 39.4-6, 22-23; 41.40-45; 42.8; 45.8-9, 26; also Gordon 1989: 7). He held substantial decision-making rights regarding rule change and managerial intervention. This in effect implied a co-determination scheme between Israel and Egypt. Specifically, Joseph masterminded Egypt's economic policies, which included active fiscal policy, division of labour and skill specialization, the hierarchical organisation of capital utilization, economic transfer of property rights, and performance-related reward systems. Future research has to analyse the various policies in more detail (see also Wagner-Tsukamoto 2001). For the present paper, Joseph's policies on property transfer and performance-related pay are especially worthwhile noting. As far as Joseph acquired property in production capital for the pharaoh (Gen. 47.13-19), this was economically organised. ${ }^{6}$ Genesis here subscribed to the concept of private property and rejected confiscation. Property was bought and sold and this happened independent of nationality and ethnic discrimination (Gen. 47.21, 27; Exod. 12.32, also Gen. 12.16). This benefited both Egypt and Israel (Gen. 47.27; see also Paris 1998: 801). Regarding remuneration issues, "special ability" (Gen. 39.3, 47.6) determined pay, promotion and fringe benefits. Joseph's career reflected this amply. Because of his

\footnotetext{
${ }^{6}$ A comparable transfer of property rights occurred in late 19th-century USA when the contractor system was abandoned in favour of functional foremanship and the functional
} 
entrepreneurial and managerial skills, he received rewards such as land, a mansion and other riches (Gen. 41.41-51, 47.6).

Joseph's policies ensured the effective utilization of human capital and prevented conflict in industrial relations. They resolved the dilemma of a potential "war about goods" (Gen. 14.16, also Exod. 1.10), as raised in the garden-of-Eden story (Wagner-Tsukamoto 2001). Cooperation emerged through a system of incentive structures that was organised through public ordering, market ordering and private ordering. His policies hint at a blueprint for handling social problems in institutional economic terms and anticipate, in degrees, suggestions of Hayek, Buchanan, Coase, North, Williamson and Vanberg.

Joseph's success is the more compelling since he resolved cooperation problems in a multi-cultural, pluralistic setting. His intervention created mutual prosperity for a community of nations, independent of the sharing of social and moral values between Egypt and Israel. His policies implied tolerance, pluralism and the rejection of value fundamentalism. This is reflected by the way the God of Genesis intervened in a non-fundamentalist but constructive manner in interactions between Egypt and Israel. Gordon linked Joseph's “wisdom” and "diplomatic skills" to the "wisdom of God" (Gordon 1989, 7-8). Institutional economic reconstruction abstracts this suggestion for cooperation principles that are developed, negotiated and implemented through 'human wisdom'. Gordon hinted at such a deconstruction of the idea of God when he attributed Joseph's success to "human wisdom that can conquer economic difficulties" and the "economic wisdom schools of Egypt" (Gordon 1989: 8, also Westermann 1997: 251-2; Gordon 1994: 21-3). The present paper specified 'human wisdom' through the concepts of dilemma analysis, economic man, incentives management, capital utilization and mutual gains. 


\section{Conclusion}

The institutional economic reconstruction of the exodus, which built on the analytical scheme summarized by Figure 1, rivals theological and religious economic approaches in terms of simplicity of constructs, conceptual coherence and explanatory power. The reconstruction suggested that Bible stories fulfil an important function regarding the ordering of human interactions, providing economic advice on cooperation problems. Exodus here specified the dilemmatic consequences of self-interested choice and rule making that disequilibrated interests. 'Paradise' was lost in a 'rationally foolish' war for goods, which left both Egypt and Israel counting losses. Genesis provided the counter-story. Economic intervention equilibrated interests of Egypt and Israel and generated mutual wealth. In this connection, the paper succeeded to conceptually interrelate the books of Genesis and Exodus through the same analytical approach. This appears mandatory because of explicit 'junctims' between both books.

Religious economics and theology conceptualise the idea of a biblical God in a highly complex, scientifically untestable manner: as an omnipotent person and creator, who exhibits multiple and largely incompatible persona in different Bible stories. For example, the final stories of Genesis portray an economically wise God whereas Exodus invokes a value fundamentalist, retaliatory God. The present paper deconstructed the idea of God in more parsimonious, non-metaphysical terms as 'cooperation catalyst' or 'cooperation saboteur'. The latter connects to the idea of the prosecutor in the prisoner's dilemma. Regarding 
institutional intervention, this implies that economics does not rely on metaphysical wisdom for solving social problems. The paper abstracted the understanding of God as a cooperation catalyst for interaction principles that imply mutual gains as interaction outcome and value pluralism as an interaction condition.

The paper suggested that the moral status of godly intervention and the interaction outcomes and conditions it reflected are ambivalent in Bible stories. In Genesis, God played a constructive, economically inspired role when intervening in interactions between Egypt and Israel. In Exodus, as in the Sodom-and-Gomorrah story and the golden-calf story, a militant, value-fundamentalist God prevented Moses and the pharaoh to preserve cooperation. Widespread suffering resulted, even for God's 'own' people. Rosy, conventional views on Moses and the God of Exodus as well as an "anti-hero thesis" regarding Joseph and the God of Genesis may need to be qualified (Wildavsky 1994; similarly Brams 1980; Gordon 1989: 1994; Paris 1998). Such apparent ambivalence regarding God's moral status has to be considered when the question of biblical morality is raised. Possibly better than asking "Where is morality 3000 years after Moses?" (Spiegel 1999: 50), the question of biblical morality may be better raised in relation to the God of Genesis and the figure of Joseph (and Jacob [Israel], too; see Wagner-Tsukamoto 2001). This puts the project of biblical ethics on constructive tracks, especially ethics which is applicable in pluralistic contexts.

Genesis and Exodus essentially document cooperation problems under pluralistic conditions. Such interaction conditions have remained a burning issue for the globalising world of the 21 st century, especially the multinational firm, the multicultural society and the global community. Genesis outlined how economic institutions can support conflict resolution in pluralistic contexts. However, pluralism was not mastered as an interaction 
condition in Exodus. Then, the 'modern', pluralistic society depicted at the end of Genesis was thrown back into 'iron age'. Indicative is not only the exodus itself but also mass executions within the Israelites own ranks in the aftermath of the exodus. In this regard, Popper's (1992: 189-90) critical comments on Moses' violent, anti-pluralistic stance in the golden-calf story fully apply.

Genesis and Exodus seemingly warn religious economics and theology to rely too heavily on 'value contracts' for resolving conflict in pluralistic contexts. Although the project of a global value contract - a "world ethos of ethical values" (Küng 1999: 70-3) - outlines, in difference to Exodus, a constructive, behavioural route to conflict resolution, its viability may be in doubt. It is likely to be less effective and less efficient than economic intervention, especially when pluralistic interaction conditions are met. Costs for generating a value consensus under pluralistic conditions or for overturning pluralism as an interaction condition are likely to be prohibitively high (see Wagner-Tsukamoto 2003; 2001). Even if a common denominator for a global value consensus could be found, it is difficult to see how a global value contract could be effectively and efficiently enacted without the support of economic institutions. In addition, moral reservation can be raised against this project because of its potentially anti-pluralistic nature. Economics has much to offer in this respect. By grounding institutional analysis and intervention in the model of economic man and an economic dilemma structure, pluralism presents no obstacle to resolving social conflict. The institutional economic assessment of Bible stories which involve Egypt and Israel forcefully underline this point. 


\section{References}

Axelrod, R.

1986 An Evolutionary Approach to Norms. American Political Science Review 80 (4): 1095-1111.

Becker, G. S.

1976 The Economic Approach to Human Behavior. Chicago, Ill: The University of Chicago Press.

1993 The Economic Way of Looking at Behavior. Journal of Political Economy 101, $385-409$.

Brennan, G.

1996 Selection and the Currency of Reward, in R. E. Goodin (ed.), The Theory of Institutional Design. Cambridge: Cambridge University Press, 256-275.

Brams, S. J.

1980 Biblical Games: A Strategic Analysis of Stories of the Old Testament.

Cambridge, MA: MIT Press.

Buchanan, J. M.

1975 The Limits of Liberty. Between Anarchy and Leviathan. Chicago, Ill: University of Chicago Press. 
1987a Economics: Between Predictive Science and Moral Philosophy. College Station: Texas A\&M University Press.

1987b The Constitution of Economic Policy. American Economic Review 77, 243 250.

1995 Individual Rights, Emergent Social States, and Behavioral Feasibility. Rationality and Society 7 (2): 141-150.

Coase, R. H.

1984 The New Institutional Economics. Journal of Institutional and Theoretical Economics 140 (1): 229-231.

Etzioni, A.

1988 The Moral Dimension. Towards a New Economics. New York: Free Press.

Gordon, B.

1989 The Economic Problem in Biblical and Patristic Thought. Leiden and New York: Brill.

1994 Theological Positions and Economic Perspectives in Ancient Literature. In Economics and Religion: Are They Distinct?, edited by H. G. Brennan and A. M. Waterman, 19-40. Boston: Kluwer.

Hardin, G.

1968 The Tragedy of the Commons. Science 162: 1243-48. 
Hardin, R.

1996 Institutional Morality. In The Theory of Institutional Design, edited by R. E. Goodin, 126-153. Cambridge, UK: Cambridge University Press.

Hayek, F.

1949 Individualism and Economic Order. London: Routledge \& Kegan Paul.

1960 The Constitution of Liberty. London: Routledge \& Kegan Paul.

1976 Law, Legislation and Liberty: The Mirage of Social Justice, Volume 2. London: Routledge \& Kegan Paul.

Hodson, G.

1967 The Hidden Wisdom in the Holy Bible. London: Theosophical Publishing House.

Hofstadter, D. R.

1979 Gödel, Escher, Bach. An Eternal Golden Braid. London Penguin.

Hollis, M.

1994 The Philosophy of Social Science. Cambridge, UK: Cambridge University Press.

Homann, K 
1990 Ökonomik und Ethik. Conference Paper, 5th Symposium “Kirche heute”, 1113 October 1990. Augsburg, Germany.

1994 Homo Oeconomicus und Dilemmastrukturen. In Wirtschaftspolitik in offenen Volkswirtschaften, edited by H. Sautter, 387-411. Göttingen, Germany: Vandenhoeck \& Ruprecht.

1997 Sinn und Grenze der ökonomischen Methode in der Wirtschaftsethik, Volkswirtschaftliche Schriften 478: 1-42.

1999 Zur Grundlegung einer modernen Gesellschafts- und Sozialpolitik: Das Problem der Sozialen Ordnung. In Soziale Marktwirtschaft im nächsten Jahrtausend, edited by U. Blum, W. Esswein, E. Greipl, H. Hereth and S. Müller, 119-148. Stuttgart, Germany: Schäffer-Poeschel.

Homann, K. and A. Suchanek

1989 Methodologische Überlegungen zum ökonomischen Imperialismus, Analyse \& Kritik 11 (1): 70-93.

2000 Ökonomik. Eine Einführung, Tübingen: Mohr Siebeck.

Knight, F. H.

1948 Risk, Uncertainty and Profit, 3rd edition. Boston: Houghton.

Küng, $\mathrm{H}$.

1999 Leitplanken für die Moral. Der Spiegel 51, 20.12.1999: 70-73. 
Lakatos, I.

1970 Falsification and the Methodology of Scientific Research Programmes. In Criticism and the Growth of Knowledge, edited by I. Lakatos and A. Musgrave, 91-196. Cambridge, UK: Cambridge University Press.

1978 The Methodology of Scientific Research Programmes. Cambridge, UK: Cambridge University Press.

Libecap, G. D.

1989 Distributional Issues in Contracting for Property Rights, Journal of Institutional and Theoretical Economics 145: 6-24.

Luce, R. D. and H. Raiffa

1957 Games and Decision: Introduction and Critical Survey. New York: J. Wiley.

Margolis, $\mathrm{H}$.

1982 Selfishness, Altruism and Rationality. Cambridge, UK: Cambridge University Press.

Maskin, E. S.

1994 Conceptual Economic Theory. In The Role of Economic Theory, edited by P. A. Klein, 187-196. Boston: Kluwer.

Miller, G. P. 
1993 Ritual and Regulation: A Legal-Economic Interpretation of Selected Biblical Texts. Journal of Legal Studies 21: 477-501.

1994 The Legal-Economic Approach to Biblical Interpretation. Journal of Institutional and Theoretical Economics 150 (4): 755-762.

Neumann, von, J. and O. Morgenstern

1947 Theory of Games and Economic Behavior. Princeton, NJ: Princeton University Press.

North, D.

1993 Institutions and Credible Commitment. Journal of Institutional and Theoretical Economics (149) 1: 11-23.

Noth, M.

1966 Exodus. A Commentary. London: SCM Press.

Nyland, C.

1996 Taylorism, John R. Commons and the Hoxie Report. Journal of Economic Issues 30 (4): 985-1016.

1998 Taylorism and the Mutual-Gains Strategy. Industrial Relations 37 (4): 519542.

Paris, D. 
1998 An Economic Look at the Old Testament. In Ancient and Medieval Economic Ideas and Concepts of Social Justice, edited by S. T. Lowry and B. Gordon, 39-103. New York: Brill.

Penrose, R.

1989 Shadows of the Mind. Oxford, UK: Oxford University Press.

Persky, J.

1995 The Ethology of Homo Economicus. Journal of Economic Perspectives 9 (2): $221-231$.

Popper, K.

1978 Conjectures and Refutations: The Growth of Scientific Knowledge. London: Routledge \& Kegan Paul.

1992 In Search of a Better World. London: Routledge.

Reventlow, H. G.

1985 Problems of Old Testament Theology in the Twentieth Century. London: SCM Press.

Sen, A. K.

1990 Rational Fools: A Critique of the Behaviourial Foundations of Economic Theory. In Beyond Self-interest, edited by J. J. Mansbridge, 25-43. Chicago, 
Ill: University of Chicago Press.

Simon, H. A.

1976 Administrative Behavior, 3rd revised edition. New York: Free Press.

1993 Altruism and Economics. The American Economic Review. Papers and Proceedings 83 (2): 156-161.

1997 An Empirically Based Microeconomics. Cambridge, UK: Cambridge University Press.

Suchanek, A.

1993 Der homo oeconomicus als Heuristik, Working Paper No. 38. Catholic University of Eichstaett at Ingolstadt, Germany: Department of Management and Economics.

1994 Ökonomischer Ansatz und theoretische Integration. Tübingen, Germany: Mohr-Siebeck.

Stigler, G. J. and G. S. Becker

1977 De Gustibus Non Est Disputandum. American Economic Review 67 (2): 76-90.

Taylor, F. W.

1903 Shop Management. Reprinted in F. W. Taylor (ed.), 1964. Scientific Management, London: Harper and Row.

1911 The Principles of Scientific Management. Reprinted in F. W. Taylor (ed.), 
1964. Scientific Management. London: Harper and Row.

1912 Taylor's Testimony Before the Special House Committee. Reprinted in F. W. Taylor (ed.), 1964. Scientific Management. London: Harper and Row.

Tullock, J.

1981 The Old Testament Story. Englewood Cliffs, NJ: Prentice-Hall.

Vanberg, V.

1994 Rules and Choice in Economics. London: Routledge.

Wagner-Tsukamoto, S. A.

2000 An Institutional Economic Reconstruction of Scientific Management: On the Lost Theoretical Logic of Taylorism”, Discussion Paper No. 2000/14. University of Leicester, UK: Management Centre/Department of Economics. Publication forthcoming in the Academy of Management Review.

2001 Economics of Genesis. On the Institutional Economic Deciphering and Reconstruction of the Legends of Genesis. Journal of Interdisciplinary Economics 12 (3): 249-287.

2003 Human Nature and Organization Theory: On the Institutional Economic Approach. Cheltenham and New York: Edward Elgar.

Westermann, C.

1987 Genesis 37-50: A Commentary. London: SPCK. 
Wildavsky, A.

1994 Survival Must Not Be Gained Through Sin: The Moral of the Joseph Stories Prefigured Through Judah and Tamar. Journal for the Study of the Old Testament 62: 37-48.

Williamson, O. E.

1975 Markets and Hierarchies. Analysis and Antitrust Implications. New York: Free Press.

1985 The Economic Institutions of Capitalism. New York: Free Press.

1998 Human Actors and Economic Organization. Conference Paper, 7th Biannual Meeting of the International Joseph Schumpeter Society, June 1998. Vienna, Austria 